\title{
Lateral
}

JOURNAL OFTHE CULTURALSTUDIESASSOCIATION

Corinne Mitsuye Sugino, "Review of 'Postcolonial Grief: The Afterlives of the Pacific Wars in the Americas' by Jinah Kim (Duke University Press)," Lateral 8.2(2019).

https://doi.org/10.25158/L8.2.19

This content is licensed under a Creative Commons Attribution 4.0 International License. Copyright is retained by authors.

Book Reviews

Issue 8.2 (Fall 2019)

\section{Review of Postcolonial Grief: The Afterlives of the Pacific Wars in the Americas by Jinah Kim (Duke University Press)}

\section{Corinne Mitsuye Sugino}

\begin{abstract}
Jinah Kim's Postcolonial Grief engages with the transnational politics of grief, mourning, and militarization across the Pacific. By examining literature and film produced by Japanese and Korean persons across the Asian diaspora, Kim reveals the ways in which loss and melancholia act as insurgent cultural forces. She considers how, despite silencing mechanisms which valorize narratives of reconciliation and pathologize the grief of colonized subjects, colonialism continues to haunt the present. A rich engagement with the overlapping histories of violence across the Pacific, Kim effectively and carefully considers the relationship between liberal narratives of reconciliation, loss, and colonial violence.
\end{abstract}

Postcolonial Grief: The Afterlives of the Pacific Wars in the Americas. By Jinah Kim.

Durham, NC: Duke University Press, 2019. Pp. 200. (paper) ISBN 9781478002796

In an exploration of twentieth and twenty-first century US militarization across the Pacific, Jinah Kim contends with how melancholia and loss act as insurgent cultural forces. This text can be situated within Kim's larger scholarly trajectory, which explores the transnational politics of migration, war, and postcolonialism, especially between Asia and the Americas. In Postcolonial Grief, Kim reveals how histories of colonial violence continue to haunt the present, contending that liberal discourses of progress only address loss through reconciliation and "proper" healing. This demand for reconciliation enlists suffering Asian figures in service of the nation state's project of capitalist expansion. While Western narratives of mourning revolve around progress, reconciliation, and closure, Kim asks us to face how unresolved violence in the Pacific constitutes an incommensurable melancholia. Kim argues that this melancholia creates fear of an uncertain future and is surveilled, silenced, and demonized by the state as a pathological inability to move on from past violence. Thus, melancholia and loss constitute insurgent cultural forces that threaten the silences and forced reconciliation surrounding colonial violence by the US and Japan.

For Kim postcolonialism does not designate the end of colonialism, but instead the way decolonization is deferred and colonialism persists in a modified state. "Postcolonial grief" names the "structure of feeling across the Pacific Arena" produced by cultural products that seek to address state violence and the ways in which they reference each other's histories (17). Grief and mourning not only operate temporally as they yoke the past into the present/future, but also spatially insofar as certain spaces remain haunted by unresolved violence. Kim's theoretical framework builds on Fanonian anti-colonialism, as well as psychoanalysis and transnational feminism, turning to literature and film produced by Japanese and Korean persons across the Asian diaspora in order to consider their experiences and how they engage with a history enmeshed in colonial violence. As she 
explains in the introduction, these cultural products reveal the influence of US militarism in the area and the affective forces they continue to exert.

Kim does not shy away from the complexities of multiple histories of violence but instead addresses how they interact, enable, and draw on each other. Chapter One reads Fanon's The Wretched of the Earth alongside Hisaye Yamamoto's "A Fire in Fontana." Pathologized and rendered illegitimate, grief by colonized subjects constitutes a form of insurgency because they refuse closure or assimilation to colonialism. Chapter Two considers the 1992 Los Angeles Riots, investigating Dai Sil Kim-Gibson's Sa-I-Gu and Héctor Tobar's The Tattooed Soldier. These works connect the riots to a larger anti-militarist stance. They enact "racial cognitive remapping" that facilitates linkages between Asian, Black, and Latino experiences of state violence and connect "the neoliberal economy and the structure of global cities such as Los Angeles to U.S. military domination across the Pacific Arena" (62). Chapter Three turns to "transpacific noir" in literature and film, arguing that the refusal of colonial subjects to heal functions as a source of anxiety in the genre. Investigating Sam Fuller's The Crimson Kimono and Naomi Hirahara's Summer of the Big Bachi, Kim demonstrates how unhealed wounds are conjured through the very silence imposed on them. She attends to Korean narratives that challenge the legacy of Japanese colonialism and US silencing mechanisms by refusing the language of overcoming and resiliency. Chapter Four juxtaposes Teresa Ralli and José Watanabe's Antigona, with Ann Patchett's Bel Canto, and Jennifer Egan's “The Liberation of Lori Benson," in addressing the Movimiento Revolucionario Túpac Amaru (MRTA) 1996 takeover of the Japanese Ambassador's home in Lima. In doing so, Kim maps the way in which Patchett's and Egan's texts represent neoliberal feminist narratives that silence mourning and invisibilize state violence. The figure of Antigone-whose brother's dead body is left to rot publicly in order to terrorize the city-presents an emblem for thinking about Peru and the MRTA members killed in the crisis. Moreover, it points to how the US "colluded and created conditions abetting the refusal to see state terrorisms" (89). Even in the epilogue Kim refuses the demand for closure, turning to Obama's visit to the Hiroshima Peace Memorial in 2016 and the ways that it effaced the unrecognized Korean victims of Japanese violence.

Though the book presents a rich engagement with overlapping histories of Japanese and Korean people, the relationship many of these figures have to enduring forces of antiblackness is less clear. Chapter One engages with Fanon in relation to Yamamoto's "A Fire in Fontana," set during the battle for redress for Japanese internment. In addition to Kim's engagement with anticolonialism, I would have liked to see a more robust engagement with Fanon's more specific analysis of blackness. Kim's acknowledgement that black people were not afforded the same luxuries as Yamamoto's Japanese protagonist was a missed opportunity to more thoroughly engage the complexity offered by Fanon's comparative analysis of the violence faced by black and non-black colonized subjects. Additionally, in Chapter Two, I wish Kim would have contended more with the legacies of anti-blackness perpetuated by Korean storeowners leading up to the LA riots. For example, in addition to the LAPD beating of Rodney King, the 1991 murder of Latasha Harlins by Korean-American storeowner Soon Ja Du also served as an important catalyst for the rebellion. This could have contributed to an even more nuanced understanding of the overlapping histories of violence at play. Nevertheless, these oversights do not undermine the importance of Kim's work. She provides fruitful grounds for considering the forces of colonial domination and postcolonial loss on the present. Postcolonial Grief powerfully uncovers overlapping histories of violence across the Pacific and carefully considers the relationship between grief, silencing, and reconciliation. Kim convincingly demonstrates the way that melancholia and loss constitute powerful forces in the Pacific as wounds that refuse to heal yet open up new (im)possibilities for relating to violence 
outside of liberal humanist frameworks of reconciliation. Postcolonial Grief is thus invaluable for those interested in affect studies, settler colonial studies, cultural studies, communication, and Asian-American history.

\section{$\underline{\dot{B} \text { Bio }}$}

\section{Corinne Mitsuye Sugino}

Corinne Sugino is a PhD student in the Department of Communication at the University of Pittsburgh. Her research interests lie at the intersection of Asian American racialization, anti-blackness, multiculturalism, and rhetorical studies.

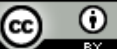

This work is licensed under a Creative Commons Attribution 4.0 International (CC BY) License, unless otherwise noted. ISSN 2469-4053 